\title{
Pengaruh Pemberian Serbuk Rimpang Kunyit (Curcuma longa L.) terhadap Jumlah Folikel Ovarium Tikus Putih (Ratus norvegicus) Premenopause
}

\section{The Effect of Giving Turmeric (Curcuma longa L.) Rhizome Powder on the Number of Ovarian Follicles in Premenopausal White Rats (Ratus norvegicus)}

\author{
Teguh Suprihatin $^{1 *}$, Sri Rahayu ${ }^{2}$, Muhaimin Rifa' $\mathbf{i}^{2}$, Sri Widyarti ${ }^{2}$ \\ ${ }^{1}$ Departemen Biologi, Fakultas Sains dan Matematika, Universitas Diponegoro, Semarang. \\ ${ }^{2}$ Jurusan Biologi, Fakultas Matematika dan Ilmu Pengetahuan Alam, Universitas Brawijaya, Malang. \\ *Email: teguhsuprihatin@lecturer.undip.ac.id
}

Diterima 13 Agustus 2020 / Disetujui 2 Oktober 2020

\begin{abstract}
ABSTRAK
Penurunan jumlah folikel ovarium secara drastis karena peningkatan kadar hormon FSH adalah kondisi umum pada wanita premenopause. Penelitian bertujuan mengetahui potensi serbuk rimpang kunyit dalam menghambat laju penurunan jumlah folikel ovarium pada tikus putih premenopause. Hewan uji adalah 30 ekor tikus putih betina, galur Wistar, usia 12 bulan, bobot 200-250 g. Hewan uji dibagi menjadi 6 kelompok, yaitu kelompok kontrol negatif (P0), diberi perlakuan akuades $4 \mathrm{ml} /$ hari; kelompok kontrol positif (P1), diberi perlakukan serbuk kurkumin $6,75 \mathrm{mg} / \mathrm{kg}$ BB; kelompok perlakuan 1 (P2), diberi perlakukan serbuk kunyit $100 \mathrm{mg} / \mathrm{kg} \mathrm{BB}$; kelompok perlakuan 2 (P3), diberi perlakukan serbuk kunyit $200 \mathrm{mg} / \mathrm{kg} \mathrm{BB}$; kelompok perlakuan 3 (P4), diberi perlakukan serbuk kunyit $400 \mathrm{mg} / \mathrm{kg}$ BB; dan kelompok perlakuan 4 (P5), diberi perlakukan serbuk kunyit 800 $\mathrm{mg} / \mathrm{kg}$ BB. Perlakuan per oral setiap hari selama 27 hari. Penelitian menggunakan Rancangan Acak Lengkap, data jumlah folikel ovarium dianalisis menggunakan ANOVA dan dilanjutkan dengan Uji BNJ. Kelompok perlakuan serbuk rimpang kunyit dengan dosis $200 \mathrm{mg} / \mathrm{kg}$ BB menunjukkan peningkatan jumlah folikel primer dan jumlah folikel antral tertinggi yaitu $9,7 \pm 1,52$ atau sebesar $262,16 \%$ dan $6,7 \pm 0,57$ atau sebesar $181,08 \%$ dibandingkan dengan kelompok kontrol negatif.
\end{abstract}

Kata kunci: foikel primer, folikel antral, kurkumin, FSH.

\begin{abstract}
Drastic reduction in the number of ovarian follicles due to increased levels of the hormone FSH is a common condition in premenopausal women. The study aims to determine the potential of turmeric powder in inhibiting the rate of decline in the number of ovarian follicles in premenopausal white rats. Animals were 30 female white rats, Wistar strain, 12 months old, weight 200-250 g. Animals were divided into 6 groups, namely the negative control group (P0), treated with distilled water $4 \mathrm{ml} /$ day; positive control group (P1), treated with curcumin powder $6.75 \mathrm{mg} / \mathrm{kg} \mathrm{BW}$; treatment group $1(\mathrm{P} 2)$, treated with turmeric powder $100 \mathrm{mg} / \mathrm{kg} \mathrm{BW}$; treatment group 2 (P3), treated with turmeric powder $200 \mathrm{mg} / \mathrm{kg} \mathrm{BW}$; treatment group 3 (P4), treated with turmeric powder $400 \mathrm{mg} / \mathrm{kg} \mathrm{BW}$; and treatment group 4 (P5), were given turmeric powder $800 \mathrm{mg} / \mathrm{kg}$ body weight. Treatment orally every day for 27 days. Research using a completely randomized design, data on the number of ovarian follicles were analyzed using ANOVA and continued with BNJ Test. The turmeric rhizome powder treatment group with a dose of $200 \mathrm{mg} / \mathrm{kg}$ BW showed an increase in the number of primary follicles and the highest number of antral follicles, $9.7 \pm 1.52$ or $262.16 \%$ and $6.7 \pm 0.57$ or $181.08 \%$ compared to the negative control group.
\end{abstract}

Keywords: primary follicle, antral follicle, curcumin, FSH. 


\section{PENDAHULUAN}

Kemampuan reproduksi pada wanita akan mengalami penurunan seiring dengan pertambahan usia. Kapasitas reproduksi wanita secara alami mencapai puncak pada usia 20 tahun, kesuburan akan mengalami penurunan secara drastis pada usia sekitar 30 tahun dan akhirnya memasuki masa menopause pada usia rata-rata 50-51 tahun (Agarwal et al., 2012). Penurunan kemampuan reproduksi pada wanita seiring dengan pertambahan usia, terlihat pada penelitian yang dilakukan di Amerika Serikat pada 120.000 peserta program embrio transfer. Hasil penelitian menunjukkan bahwa pada wanita usia dibawah 35 tahun keberhasilan program embrio transfer mencapai $45 \%$ kelahiran, $24 \%$ pada wanita usia 35-37 tahun, $19 \%$ pada wanita usia 38-40 tahun, $8 \%$ pada wanita usia $41-428 \%$, dan $4 \%$ pada wanita usia diatas 42 tahun (Wright et al., 2006).

Penurunan kapasitas reproduksi pada wanita usia diatas 35 tahun diidentifikasikan sebagai aging ovarium, yang ditandai antara lain dengan penurunan jumlah folikel ovarium secara drastis, penurunan kadar hormon estrogen, siklus estrus yang tidak teratur. Faktor penyebab pasti terjadinya aging ovarium belum dapat secara jelas diketahui (Li et al., 2012). Berdasarkan teori free radical theory of aging, menyatakan bahwa Reactive Oxygen Species (ROS), yang diproduksi oleh mitokondria akan menyebabkan kerusakan pada mitokondria itu sendiri ketika jumlahnya meningkat seiring dengan pertambahan usia dan melebihi kemampuan homeostasis sel. Kerusakan pada mitokondria akan mengganggu kinerja sel secara keseluruhan dan akan memicu terjadinya penyakitpenyakit degeneratif yang berhubungan dengan aging (Tatone et al., 2008).

$R O S$ yang diduga sebagai pemicu terjadinya aging ovarium, selain berasal dari metabolisme energi pada mitokondria sel granulosa, juga dihasilkan dari proses steroidogenesis. Produksi ROS yang tinggi dan melebihi kemampuan homeostasis sel akan mengakibatkan kerusakan berbagai komponen seluler seperti DNA, RNA, protein dan lipid. Kerusakan akan berlanjut pada mitokondria sel granulosa, mengganggu kinerja sel granulosa secara keseluruhan terutama pada proses proliferasi, dimana dukungan terhadap perkembangan oosit akan terganggu (Tatone and Amicarelli, 2012). Kondisi ini akan berujung pada terganggunya proses folikulogenesis dan bisa mengakibatkan terjadinya atresia folikel (Valko et al., 2007).

Keluhan yang menyertai terjadinya aging ovarium pada wanita usia 30 - 40 tahun seringkali dilakukan pengobatan dengan terapi. Terapi pada wanita menjelang masa menopause yang selama ini banyak dilakukan adalah secara hormonal yaitu dengan terapi sulih hormon (hormon replacement therapy atau HRT dan estrogen replacement therapy atau ERT). Efektivitas hormon estrogen dalam mengatasi keluhan menjelang menopause sangat tinggi, tetapi pada terapi hormon ini terdapat efek samping pada wanita yang mempunyai riwayat penyakit kanker payudara, kanker endometrium, sirosis hati, hipertensi, dan hiperlipidemia (Baziad, 2003). Dewasa ini terapi sulih hormon sudah mulai ditinggalkan dan beralih ke bahan obat yang lebih alami dan tidak menimbulkan efek samping (Wright et al., 2006).

Tanaman kunyit telah lama digunakan sebagai tanaman obat. Senyawa kurkumin pada tanaman kunyit diyakini berpotensi sebagai antikanker, antiviral, antiinflamasi dan antioksidan (Atef et al., 2014). Kurkumin memiliki aktivitas hepatoprotektif, cardioprotektif, antifungal dan, antioksidan. Kandungan kurkumin pada serbuk rimpang kunyit dapat berfungsi sebagai antioksidan (Shen et al., 2012). karena kurkumin dapat mengaktivasi agen transkripsi yaitu Nuclear related factor 2 (Nrf2) yang berperanan penting dalam transkripsi kelompok enzim detosifikasi fase II (phase II detoxification enzymes) seperti glutathione S-transferase (GST), NAD $(P) H$ quinone oxireductase 1 (NQO1) dan glutamylcystein synthetase (GCS). Enzim - enzim detoksifikasi fase II ini berfungsi melindungi sel dari radikal bebas terutama dari kelompok $R O S$ (Reyes et al., 2013).

Kandungan senyawa kurkumin pada tanaman kunyit juga dapat berfungsi sebagai peluruh radikal bebas (scavenger) intra seluler dari molekul oksidatif seperti $\mathrm{H}_{2} \mathrm{O}_{2}, \mathrm{HO}^{\bullet}$, dan $\mathrm{ROO}^{\bullet}$, melalui dua gugus fenolik dan satu gugus metilen $\mathrm{CH}_{2}$ yang dimiliki oleh kurkumin. Kemampuan kurkumin 
sebagai peluruh radikal bebas intra seluler akan melindungi sel dari toksisitas radikal bebas terutama dari kelompok ROS (Barzegar and Movahedi, 2011)

Tanaman kunyit juga mengandung fitosteroid ( $\beta$-sitosterol) ( $\mathrm{Li}$ et al., 2011). Fitosteroid diduga dapat berfungsi sebagai prekursor sintesis hormon steroid seperti estrogen karena secara struktural dan fungsional, fitosteroid memiliki kemiripan dengan kolesterol yang merupakan prekursor alami sintesis hormon steroid. Efek estrogenik dari fitosteroid ( $\beta$-sitosterol) dan kemampuan kurkumin dalam mengaktivasi $\mathrm{Nrf2}$, untuk memicu transkripsi enzim - enzim detoksifikasi fase 2 seperti enzim GST yang bersifat sitoprotektif, serta kemampuan kurkumin sebagai peluruh radikal bebas diharapkan dapat membantu memperbaiki penurunan jumlah folikel ovarium pada wanita, yang dalam penelitian ini akan diujicobakan efek pemberian serbuk rimpang kunyit pada tikus putih strain Wistar (Rattus norvegicus) premenopause.

\section{METODE PENELITIAN}

\section{Rancangan Penelitian}

Penelitian eksperimental laboratorik, menggunakan Rancangan Acak Lengkap (RAL) dengan 6 kelompok perlakuan, setiap kelompok perlakuan masing-masing diulang sebanyak 5 kali ulangan ; P0 : kontrol negatif tanpa pemberian serbuk rimpang kunyit (akuades), P1 : kontrol positif dengan pemberian serbuk kurkumin dosis $6,75 \mathrm{mg} / \mathrm{kg} \mathrm{BB}, \mathrm{P} 2$ : perlakuan serbuk rimpang kunyit dosis $100 \mathrm{mg} / \mathrm{kg} \mathrm{BB}, \mathrm{P} 3$ : perlakuan serbuk rimpang kunyit dosis $200 \mathrm{mg} / \mathrm{kg} \mathrm{BB}, \mathrm{P} 4$ : perlakuan serbuk rimpang kunyit dosis $400 \mathrm{mg} / \mathrm{kg} \mathrm{BB}, \mathrm{P} 5$ : perlakuan serbuk rimpang kunyit dosis $800 \mathrm{mg} / \mathrm{kg}$ $\mathrm{BB}$.

\section{Hewan Uji}

Hewan uji adalah tikus putih betina (Rattus norvegicus) strain Wistar, usia 12 bulan yang diperkirakan sudah memasuki masa premenopause, bobot tikus antara 200-250 g, sebanyak 30 ekor. Perlakuan serbuk rimpang kunyit diberikan setiap hari per oral selama 27 hari.

\section{Serbuk Rimpang Kunyit}

Serbuk Rimpang kunyit diperoleh dari Laboratorium Balittro, Bogor. Rimpang kunyit dipanen dari tanaman kunyit yang telah berusia 8 bulan, dipilih rimpang utama dengan panjang sekitar 5-7 cm dan diameter 1-1,5 cm. Rimpang kunyit dibersihkan dengan dicuci menggunakan air sampai bersih kemudian diiris tipis dan dikeringanginkan sampai kering. Pengeringan dilakukan selama kurang lebih 2 minggu sampai kandungan air hanya tinggal sekitar $10 \%$. Irisan tipis rimpang kunyit yang sudah kering kemudian diblender sampai terbentuk serbuk rimpang kunyit (turmeric). Selanjutnya dilakukan pengayakan pada serbuk rimpang kunyit dengan menggunakan ayakan yang berukuran 200mesh.

\section{Preparasi Histologi}

Hari ke 28 penelitian diakhiri, hewan coba kemudian didislokasi leher dan dilanjutkan dengan pembedahan untuk isolasi organ ovarium. Preparasi histologis ovarium menggunakan metode parafin dan dilanjutkan dengan pewarnaan HE. Slide preparat hasil pewarnaan HE kemudian diamati dibawah mikroskop untuk menghitung jumlah folikel. Pembuatan preparat histologis organ ovarium pada penelitian ini menggunakan metode parafin dengan pewarnaan Hematoxylin - Eosin berdasarkan prosedur Suntoro (1983).

\section{HASIL DAN PEMBAHASAN}

Hasil pembuatan preparat organ ovarium tikus putih premenopause menggunakan metode parafin dan dilanjutkan dengan pewarnaan Hematoksilin-Eosin (HE) tampak pada gambar 1. Preparat digunakan untuk menghitung jumlah folikel dan korpus luteum pada ovarium hewan coba setelah perlakuan serbuk rimpang kunyit. Pengamatan preparat dan penghitungan jumlah folikel dilakukan dibawah mikroskop. Hasil uji ANOVA dan uji BNJ terhadap data jumlah folikel pada ovarium tikus putih premenopause setelah pemberian perlakuan serbuk rimpang kunyit dengan metode pewarnaan Hematoxilin-Eosin, seperti ditunjukkan pada Tabel 1 . 
Hasil analisis menunjukkan terdapat perbedaan secara signifikan pada jumlah folikel primer dan jumlah folikel antral, sedangkan pada jumlah folikel primordial, jumlah folikel sekunder dan jumlah korpus luteum terdapat perbedaan yang tidak signifikan antara kelompok perlakuan kontrol negatif (akuades) dengan kelompok perlakuan serbuk kurkumin dan perlakuan serbuk rimpang kunyit. Kelompok perlakuan serbuk rimpang kunyit dengan dosis $200 \mathrm{mg} / \mathrm{kg}$ BB menunjukkan jumlah folikel primer dan jumlah folikel antral tertinggi yaitu $9,7 \pm 1,52$ dan $6,7 \pm 0,57$. Peningkatan jumlah folikel primer dan jumlah folikel antral secara signifikan pada kelompok perlakuan serbuk kurkumin dan kelompok perlakuan serbuk rimpang kunyit dibandingkan dengan kelompok kontrol negatif (akuades) kemungkinan disebabkan adanya kandungan senyawa bioaktif kurkumin pada serbuk rimpang kunyit yang dapat berfungsi sebagai antioksidan (Shen et al., 2012) dan melindungi selsel granulosa ovarium dari radikal bebas terutama dari kelompok ROS (Reyes et al., 2013).
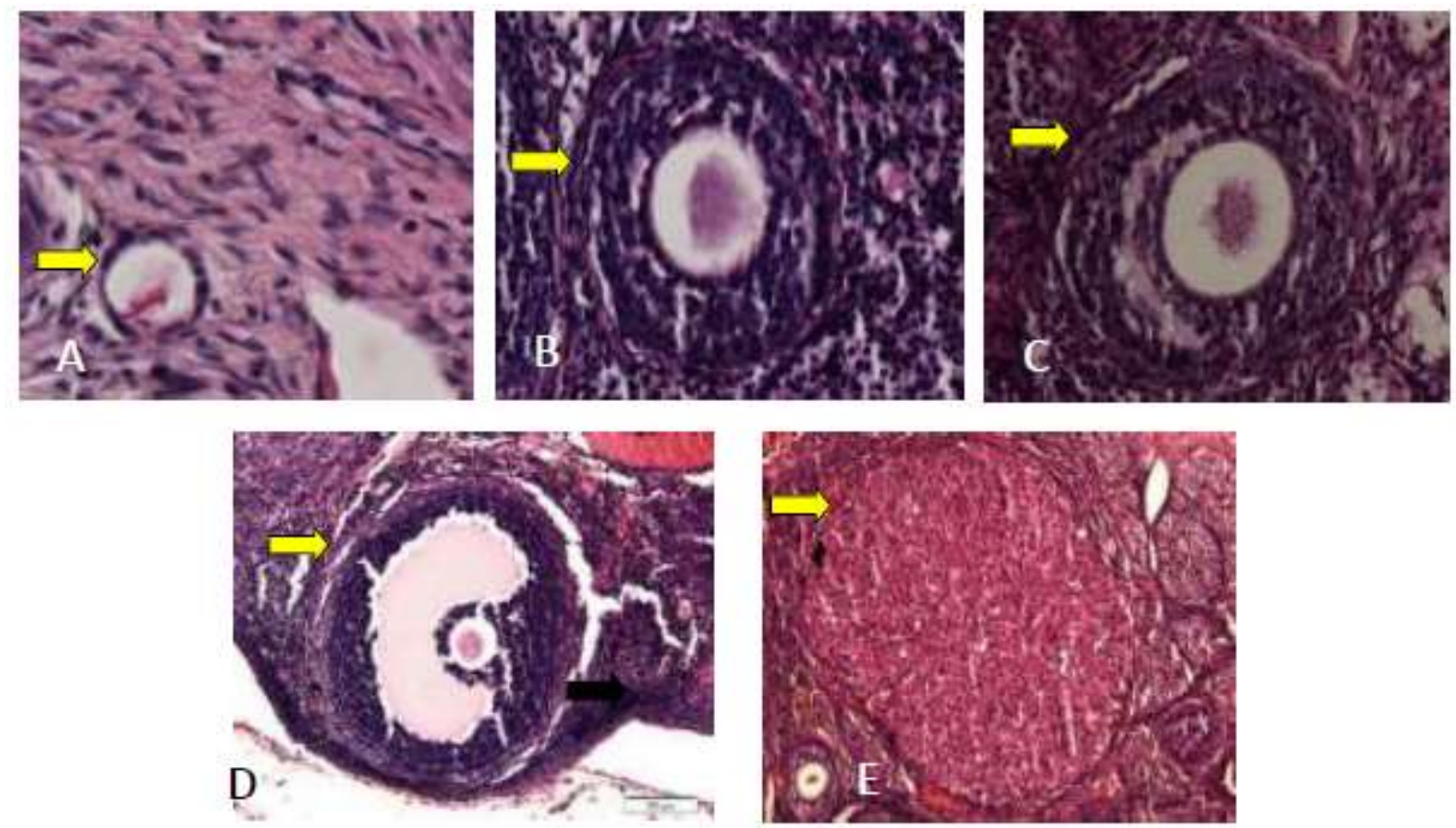

Gambar 1. Folikel ovarium tikus putih premenopause menggunakan metode pewarnaan HE. Folikel ditunjukkan dengan tanda panah. A. Folikel primordial; perbesaran 200x, B. Folikel primer; 400x, C. Folikel sekunder; 400x, D. Folikel antral; 400x, E. Korpus luteum; 100x. Menggunakan mikroskop bright field merk Olympus seri BX53.

Masa peralihan dari fase reproduktif ke fase nonreproduktif suatu individu diawali dengan suatu tahapan yang disebut dengan premenopause (Aerts et al., 2010). Tahap premenopause ditandai dengan mulai menurunnya fungsi reproduksi, menurunnya kadar hormon progesteron, estrogen, dan siklus reproduksi yang tidak teratur (Doshi and Agarwal, 2014). Penurunan fungsi reproduksi pada tahap premenopause dapat ditandai dengan penurunan jumlah dan kualitas folikel pada ovarium (Li et al., 2012). Faktor penyebab utama penurunan jumlah dan kualitas folikel diduga adalah adanya perubahan faktor lingkungan mikro ovarium seperti, peningkatan kadar radikal bebas dan advanced glycation end products (AGEs) (Tatone and Amicarelli, 2013).

Peningkatan kadar radikal bebas terutama berasal dari kelompok ROS, seperti Radikal superoksida anion, Radikal hidroksil, dan Hidrogen peroksida (Halliwell and Gutteridge, 2015). Radical Oxygen Species (ROS) adalah produk metabolisme aerobik, dimana terjadi kebocoran elektron dari dalam membran mitokondria selama proses fosforilasi oksidatif dan produksi energi. 
Carbonil Reactive Spesies (CRS) juga merupakan kelompok radikal bebas yang berasal dari metabolisme endogen sel yaitu proses glikolisis (Kunwar and Priyadarsini, 2011). Peningkatan produksi radikal bebas karena kebocoran elektron intra-mitokondria diduga erat hubungannya dengan faktor aging (penuaan) sel.

Peningkatan produksi radikal bebas seperti ROS dan CRS ketika sudah melebihi kemampuan fungsi antioksidan dari scavenger, akan mengakibatkan terjadinya gangguan pada metabolisme sel, kerusakan sel, dan dapat berujung pada terjadinya kematian sel (Bruns et al., 2015). Ketidak-seimbangan antara produksi radikal bebas dan antioksidan, akan menyebabkan gangguan kinerja seluler dan energi yang dilepaskan dari mitokondria, yang akhirnya akan mengarah ke kerusakan dan kematian sel (Subrat et al., 2013).
Penelitian ini mencoba untuk memperbaiki kondisi tidak seimbang antara produksi radikal bebas dan antioksidan, yang diduga terjadi pada individu yang memasuki masa premenopause. Serbuk rimpang kunyit yang mengandung senyawa kurkumin dan senyawa-senyawa lain yang berpotensi sebagai antioksidan eksogen diharapkan dapat membantu menyeimbangkan kondisi tersebut. Prediksi aktivitas kurkumin sebagai antioksidan dapat diketahui berdasarkan hasil analisis in silico yang meliputi nilai Probability activity $(\mathrm{Pa})$, nilai Binding affinity dan formulasi docking antara senyawa kurkumin dengan Keapl (Suprihatin et al., 2017). Nilai $P a$ dan Binding affinity senyawa kurkumin sebagai antioksidan cukup tinggi, sehingga secara in silico kurkumin dinyatakan mempunyai potensi sebagai antioksidan (Savcun et al., 2013).

Tabel 1. Jumlah folikel primordial, primer, sekunder, antral dan korpus luteum pada ovarium tikus putih premenopause dengan pewarnaan HE.

\begin{tabular}{llllllll}
\hline Parameter & Akuades & $\begin{array}{l}\text { Kurkumin } \\
\text { dosis 6,75 } \\
\mathrm{mg} / \mathrm{kg} \mathrm{BB}\end{array}$ & $\begin{array}{l}\text { Dosis 100 } \\
\mathrm{mg} / \mathrm{kg} \mathrm{BB}\end{array}$ & $\begin{array}{l}\text { Dosis 200 } \\
\mathrm{mg} / \mathrm{kg} \mathrm{BB}\end{array}$ & $\begin{array}{l}\text { Dosis 400 } \\
\mathrm{mg} / \mathrm{kg} \mathrm{BB}\end{array}$ & $\begin{array}{l}\text { Dosis 800 } \\
\mathrm{mg} / \mathrm{kg} \mathrm{BB}\end{array}$ \\
\hline Folikel primordial & $36,0 \pm 4,58^{\mathrm{a}}$ & $39,7 \pm 1,53^{\mathrm{a}}$ & $32,3 \pm 5,77^{\mathrm{a}}$ & $36,7 \pm 1,53^{\mathrm{a}}$ & $31,7 \pm 5,50^{\mathrm{a}}$ & $32,3 \pm 7,02^{\mathrm{a}}$ \\
Folikel primer & $3,7 \pm 0,57^{\mathrm{a}}$ & $6,0 \pm 1,00^{\mathrm{ab}}$ & $5,7 \pm 1,15^{\mathrm{ab}}$ & $9,7 \pm 1,52^{\mathrm{b}}$ & $8,7 \pm 2,51^{\mathrm{b}}$ & $6,7 \pm 1,52^{\mathrm{ab}}$ \\
Folikel sekunder & $2,7 \pm 0,57^{\mathrm{a}}$ & $4,7 \pm 1,15^{\mathrm{a}}$ & $2,0 \pm 1,00^{\mathrm{a}}$ & $3,3 \pm 1,52^{\mathrm{a}}$ & $3,7 \pm 0,57^{\mathrm{a}}$ & $4,0 \pm 1,00^{\mathrm{a}}$ \\
Folikel antral & $3,7 \pm 0,57^{\mathrm{ab}}$ & $6,3 \pm 1,15^{\mathrm{c}}$ & $3,3 \pm 1,52^{\mathrm{a}}$ & $6,7 \pm 0,57^{\mathrm{c}}$ & $6,0 \pm 1,00^{\mathrm{bc}}$ & $4,3 \pm 0,57^{\mathrm{abc}}$ \\
Korpus luteum & $5,3 \pm 0,57^{\mathrm{a}}$ & $7,7 \pm 0,57^{\mathrm{a}}$ & $5,7 \pm 1,15^{\mathrm{a}}$ & $7,0 \pm 1,00^{\mathrm{a}}$ & $6,7 \pm 1,52^{\mathrm{a}}$ & $6,0 \pm 1,00^{\mathrm{a}}$ \\
\hline
\end{tabular}

Keterangan : angka-angka dengan superskrip huruf yang berbeda pada lajur yang sama menunjukkan berbeda nyata $(\alpha<0,05)$.

Kelompok perlakuan serbuk rimpang kunyit dosis $200 \mathrm{mg} / \mathrm{kg}$ BB menunjukkan jumlah folikel primer, jumlah folikel antral, dan jumlah korpus luteum tertinggi, yaitu sebesar 9,7 $91,52,6,7 \pm 0,57$, dan 7,0 1,00 , dibandingkan dengan kelompok perlakuan serbuk rimpang kunyit dosis yang lain dan kontrol negatif, sedangkan pada jumlah folikel sekunder mengalami kecenderungan peningkatan dibandingkan dengan kelompok kontrol negatif tetapi tidak signifikan. Peningkatan jumlah folikel primer, sekunder, antral dan korpus luteum pada perlakuan serbuk rimpang kunyit dosis $200 \mathrm{mg} / \mathrm{kg}$ BB kemungkinan disebabkan adanya kandungan senyawa kurkumin dan senyawa-senyawa lain pada serbuk rimpang kunyit yang berfungsi sebagai antioksidan dan dapat melindungi sel-sel granulosa ovarium dari radikal bebas terutama dari kelompok
ROS. Adanya sitoproteksi pada sel granulosa ovarium akibat kerja dari antioksidan akan menjamin keberlangsungan proses proliferasi sel berjalandengan baik, sehingga diharapkan proses folikulogenesis juga berjalan dengan baik (Prasad et al., 2016).

Radikal bebas, seperti hidroksil oksida $(\mathrm{OH}-)$ dapat menyebabkan peroksidasi lipid menghasilkan senyawa yang dideteksi sebagai MDA (Halliwell and Guteridge, 2015). Pemberian serbuk rimpang kunyit dapat menurunkan kadar MDA pada sel granulosa ovarium tikus putih premenopause (Suprihatin et al., 2019), karena kemampuan senyawa kurkumin yang terdapat pada serbuk rimpang kunyit yang berfungsi sebagai antioksidan. Serbuk rimpang kunyit juga dapat mengaktivasi Nrf2 (Nuclear related factor 2), 
dimana senyawa kurkumin yang terkandung dalam serbuk rimpang kunyit akan menghalangi ikatan antara Nrf2 dengan Keapl (Suprihatin et al., 2017). Akibat ikatannya terlepas maka Nrf2 menjadi aktif bermigrasi ke dalam nukleus, berikatan dengan sMaf (small maf) dan akan mengaktivasi ARE (Antioxidant Response Element) (Paladino et al., 2018) untuk mentranskripsi gen-gen pembentuk enzim sitoprotektif seperti enzim GST (Gluthatione $S$ Transferase), yang merupakan enzim penting dalam perlindungan sel (sitoproteksi) dari kerusakan yang disebabkan oleh bahan toksik (Suzuki and Yamamoto., 2015).

Kerja enzim GST dalam memproteksi sel dengan menghambat kerja $P 21$ sebagai inhibitor siklus sel. Kondisi $P 21$ yang tidak aktif, akan memicu siklus sel untuk dapat kembali berjalan karena $E 2 F$ sebagai faktor transkripsi untuk Cyclin $E$ menjadi aktif kembali. Cyclin $E$ diperlukan oleh sel untuk masuk ke fase S (Homma et al., 2009). Peningkatan fase $S$ dapat diartikan terjadi peningkatan proliferasi sel granulosa ovarium. Kecenderungan peningkatan proliferasi sel berdasarkan penelitian Velasquez et al., (2014), yang menyatakan bahwa pemberian $0,5 \mu \mathrm{M}$ kurkumin pada stem sel olfaktori (Olfactory Ensheathing Cells) dapat menstimulasi terjadinya proliferasi sel.

Pemberian kurkumin pada mencit dewasa secara signifikan dapat meningkatkan jumlah selsel baru pada hipokampus, hal ini mengindikasikan bahwa kurkumin turut berperan dalam proses neurogenesis pada hipokampus mencit dewasa (Kim et al., 2008). Kurkumin juga dapat merangsang proliferasi dan migrasi sel-sel 3T3-L1 pre adiposa, melalui aktivasi signaling pathway $P I 3 K$ dan $M E K$ dengan menghambat secara langsung $p 38$ dan $p$-SAPK/JNK, diduga kurkumin berperanan dalam proliferasi sel pre adiposa dan migrasinya menjadi fibroblas (Kim et al., 2011).

\section{KESIMPULAN}

Pemberian serbuk rimpang kunyit dosis 200 $\mathrm{mg} / \mathrm{kg} \mathrm{BB}$ adalah dosis paling optimal, karena dapat meningkatkan jumlah folikel primer sebesar 262,16\%, dan jumlah folikel antral sebesar $181,08 \%$ pada tikus putih premenopause..

\section{UCAPAN TERIMA KASIH}

Artikel merupakan bagian dari disertasi penulis pertama. Studi program doktor telah dibiayai oleh beasiswa BPPDN, Direktorat Jenderal, Pendidikan Tinggi. Kementerian Riset, Teknologi dan Pendidikan Tinggi, Republik Indonesia.

\section{DAFTAR PUSTAKA}

Aerts, J.M.J., P.E.J. Bols. 2010. Ovarian Follicular Dynamics. A review with Emphasis on the Bovine Species. Part II: Antral Development, Exogenous Influence and Future Prospects. Reproduction domestic animal. 45:180-187.

Agarwal, A., A. Aponte-Mellado, B.J. Premkumar, A. Shaman, S. Gupta. 2012. The effects of oxidative stress on female reproduction: a review. Reproductive Biology and Endocrinology. 10:1-49.

Atef, M., M. Attia, F.A. A. Ibrahim, N.A. Abd ELLatif , S.W. Aziz . 2015 Antioxidant effects of curcumin against cadmium chloride-induced oxidative stress in the blood of rats. Journal of Pharmacognosy and Phytotherapy. 6(3):33-40.

Barzegar, A. M., A. A. Movahedi. 2011. Intracellular ROS protection efficiency and free radical-scavenging activitity of curcumin. Plos ONE 6(10) e26012. DOI:10.1371/journal.pone.0026012

Baziad, A. 2003. Menopause dan Andropouse. Yayasan Bina Pustaka Sarwono Prawihardjo. Jakarta. Hal. 25-41.

Bruns, D.R., J.C. Drake, L.M. Biela. 2015. Nrf2 signaling and the slowed aging phenotype: evidence from long-lived models. Oxidative Medicine and Cellular Longevity. 1-15

Doshi, S.B., A. Agarwal. 2014. The role of oxidative stress in menopause. Journal of Mid-life Health. 4(3):140-147.

Halliwell, B., J. M. C. Gutteridge. 2015. Free Radical in Biology Medicine $5^{\text {th }}$ Edition (preview). Oxford University Press. Oxford. United Kingdom.

Homma, S., Y. Ishii, Y. Morishima, T. Yamadori, Y. Matsuno. 2009. Nrf2 Enhances cell proliferation and resistance to anticancer drugs 
in human lung cancer.Clinical Cancer Research.15(10):3423-3434.

Kim, J.H., S.H. Park, S.W. Nam, H.J. Kwon, B.W. Kim. 2011. Curcumin stimulates proliferation, stemness acting signals and migration of 3T3L1 preadipocytes. International Journal of Molecular Medicine. 28:429-435.

Kim, S.J., T.G. Son, H.R. Park, M. Park, M.S. Kim. 2008. Curcumin stimulates proliferation of embryonic neural progenitor cells and neurogenesis in the adult hippocampus. The Jounal of Biochemistry. 283(21):14497-14505.

Kunwar, A., K.I. Priyadarsini. 2011. Free radicals, oxidative stress and importance of antioxidants in human health. Journal of Medical and Allied Sciences, 1(2):53-60.

Li, S., W. Yuan, G. Deng, P. Wang, P. Yang, B.B. Aggarwal, 2011, Chemical composition and product quality control of turmeric (Curcuma longa L.), Pharmaceuti. Crops, 2:28-54

Li, Q., X.D. Geng, W. Zheng, J. Tang, B. Xu, Q.H. Shi. 2012. Current understanding of ovarian aging. Scie. Chi. 55 (8):659-669.

Paladino, S. A. Conte, R. Caggiano, G.M. Pierantoni, R. Faraonio. 2018. Nrf2 pathway in age-related neurological disorder: insights into microRNAs. Cellular Physiology and Biochemistry.47:1951-1976

Prasad, S., M. Tiwari, A.N. Pandey, T.G. Shrivastav, S.K. Chaube. 2016. Impact of stress on oocyte quality and reproductive outcome. Journal of Biomedical Science. 23(11):36-43.Reyes, S.G., S.G. Beltrán., O.N. Campos, J.P. Chaverri. 2013. Curcumin Pretreatment Induces Nrf2 and an Antioxidant Response and Prevents Hemin-Induced Toxicity in Primary Cultures of Cerebellar Granule Neurons of Rats. Hindawi Publishing Corporation Oxidative Medicine and Cellular Longevity. http://dx.doi.org/10.1155/2013/801418.

Savcun, G.Y, E. Ozkan, E. Dulundu, U. Topaloglu et al. 2013. Antioxidant and anti-inflammatory effect of curcumin against hepatorenal oxidative injury in an experimental sepsis model in rats. Ulus Travma Acil Cerrahi Derg Turkish Journal. 19(6):507-515.
Shen, L. R., F. Xiao, P. Yuang, Y. Chen, Q. K. Gao. 2012. Curcumin-supplemented diets increase superoxide dismutase activity and mean lifespan in Drosophila. Age. DOI : 10.1007/s11357-012-9438-2. Published online in Wiley Online Library. wileyonlinelibrary.com.

Subrat, P., S.A. Santa, J. Vandana. 2013. The Concepts and Consequences of Early Ovarian Ageing: A Caveat to Women's Health. Journal of Reproduction and Infertility. 14(1):3-7.

Suntoro, H. 1983. Metode Pewarnaan (Histologi dan Histokimia). Penerbit Bharata Karya Aksara. Jakarta.

Suprihatin, T., S. Widyarti, M. Rifa'i, S. Rahayu. 2017. Computational study of curcumin as antioxidant and potential inhibitor to abrogate Keap1-Nrf2 interaction. Medicinal Plants International Journal of Phytomedicines and Related Industries. 9(3):150-153

Suprihatin, T., S. Widyarti, M. Rifa'i, S. Rahayu. 2019. Malondialdehyde (MDA) Ovary and Estradiol Blood Serum Levels of Premenopause White Rat (Rattus norvegicus) after Turmeric Powder (Curcuma longa L.) Treatment. Journal of Tropical Life Science. 3(9):237-242.

Suzuki, T., M. Yamamoto. 2015. Molecular basis of the Keap1-Nrf2 system. Free Radical Biology and Medicine. 88(part B):93-100.

Tatone, C., F. Amicarelli, M.C. Carbone, P. Monteleone, D. Caserta, R. Marci, P.G. Artini, P. Piomboni, R. Focarelli. 2008. Cellular and molecular aspects of ovarian follicle ageing. Human Reproduction. 14:131-142.

Tatone, C., F. Amicarelli. 2012. The aging ovarythe poor granulosa cell. Fertility and Sterility. 99(1):12-17.

Valko, M., D. Leibfritz, J. Moncol, M.T.D. Cronin, M. Mazur, J. Telser. 2007. Free radicals and antioxidants in normal physiological functions and human disease. The International Journal of Biochemistry and Cellular Biology. 39(1):44-84.

Velasquez J.T., M.E. Watts, M. Todorovic, L. Nazareth. 2014. Low-dose curcumin 
stimulates proliferation, migration and phagocytic activity of olfactory ensheathing cells. Plos One 9(10):1-17.

Wright, V.C., J. Chang, G. Jeng, M. Macaluso. 2006. Assisted reproductive technology surveillance-United States, 2003. MMWR Surveill Summ. 55:1-22. 